Article

\title{
Perceptions of Bioeconomy and the Desire for Governmental Action: Regional Actors' Connotations of Wood-Based Bioeconomy in Germany
}

\author{
Manuel Hafner ${ }^{1, *,+}$, Lukas Fehr ${ }^{2,+}{ }^{+}$, Jan Springorum ${ }^{1}$, Artur Petkau ${ }^{1}$ and Reinhard Johler $^{2}$ \\ 1 University of Applied Forest Sciences Rottenburg, 72108 Rottenburg a.N., Germany; \\ jan.springorum@hs-rottenburg.de (J.S.); petkau@hs-rottenburg.de (A.P.) \\ 2 Institute of Historical and Cultural Anthropology, University of Tübingen, 72070 Tübingen, Germany; \\ lukas.fehr@uni-tuebingen.de (L.F.); reinhard.johler@uni-tuebingen.de (R.J.) \\ * Correspondence: hafner@hs-rottenburg.de \\ + Both authors contributed equally to this manuscript.
}

Received: 14 October 2020; Accepted: 20 November 2020; Published: 24 November 2020

check for updates

\begin{abstract}
The term bioeconomy denotes political strategies that affect all areas of life and economy and require broad social support. Nevertheless, the term has not yet pervaded the everyday lives of many people. It is yet unclear what effects these concepts generate in the form of associations and what conflicts and political demands could be associated with them. Using an ethnographic approach, different actors from the forest and wood field of action were interviewed in two study regions in Germany, who are already, consciously or unconsciously, engaged in bioeconomy at a regional level. Different perceptions and interpretations of bioeconomies can be identified, which are often linked to political demands. These can be clustered into two groups. The first group refers to the forest as a place of primary production and demands an adaptation of forest management. The second group refers to wood as the most important raw material of bioeconomy and demands planning security necessary for change. The paper shows that, from the perspective of the interviewees, government action can contribute to the definition of concepts by sending clear signals and thus overcome the limited reach of strategy papers.
\end{abstract}

Keywords: wood-based; bioeconomy; transition; regional; governance; politics; perceptions; multi-actor

\section{Introduction}

In March 2020, the German government adopted the National Bioeconomy Strategy, which describes several guidelines and measures that shall help to establish bioeconomy in Germany [1]. For this reason, it aims to achieve holistic solutions for implementation in the areas of research funding, framework conditions, and overarching instruments. In addition to the ecological effects, social and economic conditions are also to be taken into account. The term bioeconomy has been around for several decades and has been repeatedly endowed with new attributions and meanings in science, business, and politics [2]. It dates back to the economist Nicolas Georgescu-Roegen, who pointed out the planetary limits of growth and demanded that the economy should take this into account [3]. The German bioeconomy strategy is only one of several circulating (research) strategies that draw a picture of a grand transformation of society. It encompasses all areas of life and economy, including the forestry sector, which this paper focuses on. In the scientific discourse about bioeconomy in connection with the raw material wood, the term wood-based bioeconomy is often used $[4,5]$. The prefix indicates the high relevance of the raw material for the great transformation. Although there is no uniform definition of the term, wood-based bioeconomy is usually understood as "a bio-based circular economy 
that uses lignin-containing and, therefore, hard parts of stem, branches and twigs of plants such as trees and scrubs" [5] (p. 2). The intention is to replace non-renewable raw materials with renewable raw materials for material and energy purposes.

Previous research on bioeconomy has posed the question of whether bioeconomy should be interpreted in terms of biomass or biotechnology [6]. Levidow et al. identify these interpretations as "two contending visions of the bio-economy" [7] (p. 40). Staffas et al. conclude that the two interpretations are to be understood as the divergent terms: bioeconomy (technological interpretation) and biobased economy (biomass-oriented interpretation) [8]. Hausknost et al. add the agro-ecological interpretation which is based on organic farming, broader participation, and the concept of sufficiency [9]. McCormick and Kautto argue to shift the discussion to a participatory governance that enables sustainable development in a societal dialogue [10].

Recent research activities that emphasize the role of actors in bioeconomy mostly originate from innovation-, stakeholder-, and/or policy-oriented research approaches. Therefore, bioeconomy forms an overlapping research field between economic, political, and social sciences [11]. The socioeconomic perspectives on the role of actors in innovation systems includes research questions like the importance of actor networks and strategic decision-making for technology development and diffusion [12], the importance of actors in regional knowledge production [13], or the identification of relevant bioeconomy actors [14]. Leipold et al. analyze stakeholder debates in the overlap of circular economy and bioeconomy [15]. By incorporating actors' views in transition contexts, Falcone et al. set up a framework of the social impacts of bio-based products [16] and Hausknost et al. discern stakeholders' visions about different paths of bioeconomies [9]. On the sociological side of the socioeconomic spectrum, López et al. show the actors' scope for action in bioeconomic transition with an agency approach [17]. Actor-oriented bioeconomic policy research adds the analysis of the interaction between actors and policies or institutions, for example by integrating stakeholders' expectations in a sustainable development goals framework [18] or the resulting governance aspects of this interaction in collaborative processes in European forest strategy formation against the background of bio-based economies [19].

Though the need to include views from wider societal groups is already identified [20], it has not so far been realized with an approach that incorporates technological- and biomass-oriented interpretations on a regional level and is not restricted to one of the actor-concepts mentioned above. For the present study, qualitative and ethnographic methods [21-23] were used to research two case regions in Germany, focusing on actors related to forests and wood processing. This approach intends to make the connections between political goals, economic interests and the individual views and actions of the interviewees visible. There are already several research projects that analyze and compare different bioeconomy strategies, but the perception and reception of these strategies by people in specific places along the value chains of wood and in primary production have not yet been investigated. A multi-stakeholder approach has been adopted to ensure that different perspectives are covered [24]. This paper shows how actors in the forestry and wood sector perceive the concept of wood-based bioeconomy. The focus lies on the questions:

- Which understandings of the term are circulating among regional actors?

- What demands on politics are linked to these?

In the following, the analytical framework, the methodological procedure, as well as the research data collected are presented. Afterwards, the understandings of bioeconomy and the demands on politics formulated by the interviewees are described. Finally, the results of the evaluation are discussed, and a conclusion is drawn as to what might still be necessary for the implementation of a wood-based bioeconomy. 


\section{Methods and Analytical Framework}

In the first phase, a literature research was conducted to get an overview of different concepts of bioeconomy. In addition to scientific publications, documents on the political framework conditions worldwide, at EU level and in Germany were collected. The corpus of documents included political (research) strategies, statements of (state) governments, and position papers, which were compared with a qualitative content analysis. The analysis served to develop an understanding of bioeconomy as a disparate concept that highlights different goals. Based on the assumption that in different regions, different factors influence the perceptions and opinions of the actors, a catalog of criteria for the selection of the study regions was subsequently created. Accordingly, the regions should differ in terms of their economic and ownership structures, the historical-cultural imprints of their populations, their climatic and natural conditions, their forest management structures, and in their forest administration traditions. In addition, they should be rural in character, have at least an average proportion of forest in Germany, and be known nationwide as landscapes. Based on these criteria, the Swabian Alb in Baden-Württemberg and the Lusatia-Spreewald region in Brandenburg were selected as study areas. An explorative approach was chosen to make a selection of companies, non-governmental organizations, and authorities without presuppositions [25]. This allowed becoming familiar with the research regions and their forestry and wood sector. In addition, it allowed to get a broader understanding of the perceptions of bioeconomy. Stein et al. carried out a study on the acceptance of bioeconomy in the German forestry and wood sector. Their criteria for the selection of interviewees consisted of actors that had already spoken publicly about bioeconomy and are part of the forestry and wood sector [26]. The approach chosen for this paper has a broader scope in order to get a greater variety of perceptions. Actors of different types and sectoral affiliations were interviewed on-site. The statements were synthesized in this work to a cross-regional discourse to answer questions, such as what role the term bioeconomy and its development played at a regional level and what opinions, motives, narratives, and perceptions were associated with it. At the same time, it had to be ensured that all interviewees, regardless of whether they were familiar with the concept or not, could be assigned to the bioeconomy field of action. To this end, existing value chains in the forestry and wood industry were first identified in the study regions. Along these value chains, actors were identified as potential interview partners. These actors were particularly visible within their regions as representatives of the forestry and wood industry. This means that they advertised, for example, innovative products or occupied leading positions in relevant organizations. To generate an interview cascade at the end of the interviews, the interviewees were asked for further, potentially interesting interview partners. The main interview period, with 29 of in total 33 interviews, took place between January 2019 and June 2019. Persons from forest administrations and forest enterprises, forest owner associations, companies that process, trade, certify or manage wood, from nature and environmental protection or local politics were interviewed. Participation was voluntary on request and there was no payment or expense allowance. The interview partners were assured of anonymity and the names were pseudonymized. For the data collection, guideline-based interviews were conducted consisting of questions based on theory and hypotheses [27]. The interviews were conducted in German. Passages with quotations have been translated by the authors. In the interviews, questions were asked about topics, goals, and conflicts in their field of activity as well as their personal relationship to forests and wood. The interviewees thus implicitly established connections to the wood-based bioeconomy. Only towards the end of the interviews, the interviewees were asked directly whether they were familiar with the term bioeconomy and what their comprehension was. This was intended to reduce the interviewees' influence on the answers as much as possible [28]. The interview period was continued until clear redundancies were found in the statements [29]. Table 1 gives an overview of the distribution of IPs (interview partners) across the regions, their respective professional approach to the topic, and their previous experience with the term bioeconomy. 
Table 1. Distribution of the interview partners according to their respective fields of activity in the two research regions.

\begin{tabular}{lcc}
\hline & Swabian Alb & Lusatia Spreewald \\
\hline Forest administration (state) & IP 4,9 & IP $11^{*}, 15,26$ \\
\hline Forest administration (municipal) & IP $2 *$ & IP 14,21 \\
\hline Forest owners/forestry operations & IP 3,29 & IP 23 \\
\hline Wood processing & IP $1,18^{*}, 24^{*}, 25,30,33$ & IP $5 *, 19,27$ \\
\hline Nature conservation/cultural landscape & IP $7,8,13$ & IP 12, 16, 20, 32 \\
\hline Local politics & IP 17,22 & - \\
\hline Certification/renaturation/funding & IP $10^{*}, 31 *$ & IP $6 *, 28$ \\
\hline Total & 18 & 15 \\
\hline
\end{tabular}

For the analysis of the interviewees' statements, bioeconomy served as a term from the research field in Pierre Bourdieu's sense of field theory [30]. For Bourdieu, the term of the field is variable and does not aim at the description of 'the truth.' It rather serves to visualize and connect the different systems of meanings and the respective habitus. Bioeconomy is thus not firmly defined but is fed by the different understandings. It is not a matter of differentiating between right and wrong answers, but of making the connections between the term and other topics visible. Starting from the situated knowledge of the interviewees, it is not about the objectivity of the statements, but about making visible the knowledge and related positions and perspectives [31]. At the same time, it was always a question of who defines bioeconomy and how. Not only did the interviewees have different understandings of bioeconomy, there were also different definitions in the strategy papers and research initiatives. This was due not only to the knowledge base but also to the different interests involved [32]. For an explorative approach, the interviewees' understandings of bioeconomy were regarded as their definitions and therefore the term bioeconomy was used in the plural. Bioeconomies as a field term allowed a broader understanding in order to make other interpretations of the term analyzable. At the beginning of the analysis, there was an open coding to deconstruct the field [33]. Thus, the theory-based hypotheses were expanded to include those topics of the interview partners that were not previously apparent, but exploratory. In the next step, categories were formed from this procedure and thus the material was analyzed [21]. With regard to the questions addressed in this paper, statements could be obtained from 20 of the 33 interviews. 12 of the remaining 13 interviewees could not or did not want to engage with the term and therefore did not formulate any demands towards politics. One interview had to be removed from the evaluation because the interviewee wanted to make serious retroactive changes to the transcript.

\section{Bioeconomies: Understandings and Associations of the Interview Partners}

Of 33 interviewees, eight were familiar with the term bioeconomy. Only two of the interview partners referred to the research strategy of the Federal Ministry of Education and Research [34] and the National Bioeconomy Policy Strategy [35], as well as the National Bioeconomy Strategy [1], which was still in the process of being developed at the time of the interviews. The remaining interviewees did not name any concrete connections or sources. Overall, the understanding of bioeconomies was diverse among those who knew the term. This was because they attached different importance to various aspects more or less important from their personal or professional perspective. Table 1 also shows that those interview partners who were already familiar with the term are homogeneously distributed both across the various groups and across the two study regions. Interview partners who had never heard of bioeconomies were asked to freely associate. The majority of these interviewees were close 
to the topics formulated in the strategy papers. In the following, the understanding of wood-based bioeconomies from the data collection is presented.

Regardless of their professional topic-approach, the interviewees who were already familiar with the term usually cited the substitution of fossil fuels by renewable raw materials in the economy as the central element of bioeconomies (IP 10, IP 11, IP 18, IP 24): "The entire economic cycle is currently based on fossil fuels. [ ... ] This means that the economic cycle as a whole must be transformed completely" (IP 10, Pos. 100). The change was described as imperative, desirable, and encompasses all areas of economic activity, from the primary production of raw materials to the products for the consumer. The prefix 'bio-' was equated with sustainability because fossil raw materials such as crude oil would no longer be used (IP 10). For actors from the forestry and wood sector in both regions, it seemed to be self-explanatory that wood is a guarantee for sustainability regardless of whether they were familiar with the term or not. Wood-based bioeconomies could be considered sustainable, according to a senior manager of a state-owned forestry enterprise, if "the conversion process is carried out in the way Carlowitz described sustainability, so that future generations will get the same yield from the ecosystem as we get today" (IP 11, Pos. 75). The reference to Carlowitz is often used because he was the first to develop sustainable yield forestry [36]. At the same time, interviewees questioned the blanket connection between wood and sustainability. It was also a question of how the raw material was used. One interviewee, who is active in environmental protection, associated a non-sustainable economic system with this and considered that "it is illusory to simply change everything to biobased and just keep going on" (IP 13, Pos. 188). She did not know the term bioeconomy but associates limits with growth. She referred to concepts of sufficiency and post-growth theories. For her, bioeconomy meant concentrating on "regional cycles and not an economy geared to growth" (IP 13, Pos. 143). The switch to biobased resources would hardly bring about any improvements if resource consumption were not reduced and energy saved at the same time (IP 13). The managing director of a wood-processing company also observes a tension between economy and ecology but points out that questions of sustainability must be compatible with economic conditions: "Will it cope with our sustainability concept, our thought 'We want to do something good for the environment here', will it do justice to that? Otherwise, I would not do it. But once that first question is answered, the second question is 'To what extent can we afford it?' And if we cannot afford it, then we should steer well clear of it. Because if we are broke, then I have achieved nothing at all" (IP 25, Pos. 120).

The interviewees who were already familiar with the term easily linked the concepts to the raw material wood. For the senior manager of a state-owned forestry enterprise, wood was perhaps the most important raw material for bioeconomies. For him, there was no alternative to the goals of the German government's strategy paper and wood is indispensable for its implementation: " $[\ldots$ ] if you follow this strategy, and there is no other option, then wood is the raw material of the future $[\ldots]$ " (IP 11, Pos. 22). Therefore, wood should be increasingly used as a building material. This would also allow $\mathrm{CO}_{2}$ to be bound in the long term, which would make an important contribution to achieving climate goals. The substitution of other raw materials with wood was therefore not only economically necessary but also a contribution to environmental protection. Wood was also available in the required quantities (IP 11).

In addition to changes in the forest management and the guaranteed supply of wood as a raw material, interviewees from both regions and all professions, of whom only three knew the term, mentioned a need for new, innovative technologies and products (IP 2, IP 10, IP 11, IP 18, IP 25, IP 30, IP 33). It was important to research and develop possibilities of chemical wood pulping and new material uses of wood fibers. So far, there are no established markets and a lack of products made of wood, which would allow an extensive transformation. This was related to the fact that, partly due to legislation, regulations, or lack of funding, existing ideas from the research were not feasible for the market. At the same time, a representative of a large international forest certification system saw great potential for a pioneering role for Germany: " $[\ldots$ ] because now we can say that we are a country that 
brings technologies to the market to use renewable resources for everything that is today made from fossil fuels, products or raw materials" (IP 10, Pos. 110).

The demands for research and development were repeated by various interviewees with ideas of future circular economy management in the forestry sector and the further development of concepts such as "cradle to cradle." It was emphasized that in wood-based bioeconomies, the relationship between material and energy usage of wood would change. Material usage would then become more attractive compared to direct energy usage because, in addition to the effect of long-term $\mathrm{CO}_{2}$ sequestration, it would also be possible to achieve higher added value (IP 11, IP 18, IP 25). Potentials for value creation were also seen in the regional availability and processing of wood because this was associated with greater independence from imports of other resources (IP 10, IP 18, IP 22, IP 25).

Table 2 gives an overview of the associations and the arguments, from which they were derived. Most associations occur in both groups (term familiar/not familiar). Regional disparities could not be identified.

Table 2. Understandings and associations of the interview partners.

\begin{tabular}{|c|c|c|}
\hline Argument & Term Familiar $(X)$ & Association \\
\hline Wood $=$ organic $=$ sustainable & $x$ & \multirow{2}{*}{ Sustainability } \\
\hline Regional cycles & & \\
\hline Limits to growth, sufficiency & & \multirow{3}{*}{ Raw material availability } \\
\hline Wood $=$ most important raw material in bioeconomies & $\mathrm{x}$ & \\
\hline Wood is available & $x$ & \\
\hline Cost of environmental protection & & \multirow{2}{*}{ Business-related } \\
\hline Market potential & $x$ & \\
\hline New technologies and products needed & & \multirow{2}{*}{ Innovation } \\
\hline Cradle to cradle & $x$ & \\
\hline Replace fossil by renewable resources & $x$ & \multirow{3}{*}{ Substitution } \\
\hline Timber construction, $\mathrm{CO}_{2}$ storability of wood & $x$ & \\
\hline Independence from imports & & \\
\hline
\end{tabular}

\section{Demands on Politics}

Concerning the thematic orientation of this chapter, no serious differences could be found between interview partners who already knew the term and those who did not yet know the term (See Table 1). The results presented were structured in such a way that political demands, which were mentioned by a majority of interviewees, are presented first. This is followed by individual demands. Then those which are to be assigned to clusters (e.g., all entrepreneurially active interview partners). Finally, demands are presented that were put forward by various interviewees without being able to be assigned to a specific cluster.

Most interviewees from both regions and all professions, regardless of whether they were familiar with the term or not, cited the $\mathrm{CO}_{2}$ storability of wood as the decisive argument for using this raw material. At the same time, comparisons were made with other raw materials, and their production conditions and energy consumption were discussed. According to the managing director of a wood-processing company, these advantages must be used and promoted consistently, because only wood was available in the required quantities. "The only thing that can represent bioeconomy is wood: renewable raw material in the forest, wood, storing $\mathrm{CO}_{2}$; of course, we can make it out of straw and anything else. But that is field cultivation, which is completely different from a forest. [ ... ] I think the bioeconomy is us, the forest owners, the wood industry, right up to those making chipboard, paper, or something else. Whoever somehow processes the grown trees and thus binds the $\mathrm{CO}_{2}$ in some way, 
in the medium and long term. If possible over generations and in several cascades" (IP 18, Pos. 115). Most of the interviewees therefore pointed to the need to promote wood as a building material more aggressively, e.g., in the form of inner-city densification in urban development (IP 10).

There were various demands and proposals for the choice of the political steering instrument. For example, the managing director of a wood-processing company would like to see the value-added tax for wood products reduced to seven percent (IP 25). The manager of a large private forest estate proposed financial compensation for timber construction via some kind of intervention account, inspired by the German "Ökokonto": "If you build with wood, build $\mathrm{CO}_{2}$ neutral, you will be credited with points. [... ] This will then cost nothing and will also bring an unbelievable amount because otherwise, they pay a fortune for a compensation area or ecological upgrading" (IP 30, Pos. 108). A high-ranking local politician put up a timber construction obligation for discussion. Building regulations should be made more wood-friendly: "So that people build with standards that are oriented towards wood and not with standards that are oriented towards concrete." (IP 17, Pos. 48-52). Additionally, the necessity to include environmental costs into resource utilization was emphasized. This would automatically lead to an increase in the price of fossil raw materials and thus to a more realistic market entry of bioeconomic products. The $\mathrm{CO}_{2}$ tax was also a recurring theme across all interviews. It was also argued that wood as a raw material is regionally available and that, for example, the public sector could contribute to the avoidance of $\mathrm{CO}_{2}$ emissions by choosing building materials with short transportation routes for public infrastructure (IP 13, IP 18, IP 32).

In addition, sector-specific demands on politicians were apparent. Entrepreneurially active players repeatedly state that they were waiting for political frameworks to be set. In this context, however, the promotion of bioeconomic investments was not always the top priority. Rather, they generally complained about contradictory statements, a lack of political guidelines and planning reliability. One interviewee, who is active in the timber trade, described a risk in investments that could be minimized by binding regulations: "Reliability is crucial for economic enterprises. No matter in which direction. [ ... ] and it has to be valid for a certain period of time because if they [ ... ] simply build a new site like this [ ... ] it will cost billions" (IP 1, Pos. 124). Politicians should not rely on the market alone to regulate the change described above. Existing structures were often not adapted to bioeconomic products, which, however, could be decisive for the economic efficiency of these products. An entrepreneur from the field of biobased plastics described such inhibitory regulations using the example of a newly adopted packaging ordinance. This regulation did not consider bioeconomic products, which meant that such products were regarded as impurities in the disposal process, which in turn lead to unnecessarily high disposal costs. Innovative products geared towards sustainability were thus put at a disadvantage (IP 5).

Wood as a raw material was differentiated from other renewable raw materials from agriculture. It was emphasized that only wood would be available in the required quantities (IP 2, IP 10, IP 11, IP 18, IP 25). As a consequence of the increasing substitution of fossil raw materials and energy sources with wood and wood-containing products, however, the demand would continue to rise. In this context, the head of a local authority responsible for both nature conservation and forests pointed out that wood production does not have to be sustainable by itself: " ... at some point, I will of course [ ... ] reach the limit. I cannot produce the raw material wood infinitely" (IP 2, Pos. 67). For the implementation of a wood-based bioeconomy, therefore, forest areas would have to be reforested and additional land has to be made available for silviculture-land that would then be lacking for agriculture. To prevent further pressure on agriculture, policymakers should have to take measures because soil sealing of agricultural land was simply too cheap (IP 2). Another interviewee from the field of forest certification saw unused potential in the mobilization of wood. For example, there are "afforestation areas [in the region] that are no longer used today. I clearly see the potential for increasing the volume of wood that we produce" (IP 10, Pos. 89). At the same time, some interviewees called for forest conversion to resilient forests and rejected monocultures (IP 2, IP 6, IP 14). Here, too, targeted governance was needed. A senior employee of a state-owned forestry enterprise expressed the hope "that with last year's record summer 
we can slowly set the course for this. Now we are getting an implementing regulation, a new one [in the region], which is perhaps a little better placed. This is my big goal, to get away from these pure pine stands, towards climate-plastic mixed forests" (IP 14, Pos. 22). However, the question of tree species selection was not uncontroversial in the context of this forest-related discussion, which has been going on for many years. The managing director of a large private forest owner pleaded for well-known species and argued from his practical experience: "We [have] autochthonous fir trees here, which all break down [ ... ]. We have the 'fir engraver beetle' [Pityokteines curvidens], the 'small fir bark beetle' [Cryphalus piceae], and the 'european silver fir weevil' [Pissodes piceae] inside. All three at the same time. So much for the fir's climate resistance. All the beech trees kick the bucket. The tree species, to put it in a nutshell, that causes the least problems because it causes the most problems, but we know how to deal with it, that is the spruce. It falls over in a storm and the beetle eats it when it is warm. And I can do something about both. [ ... ] I can raise it so solidly that it only falls over when the oak tree does, and then we are powerless, yes. And that is what we are doing here, and then the spruce is a great tree species, by the way, the only one you can make anything out of, the only one" (IP 3, Pos. 40). A senior employee of a state-owned forestry enterprise mentioned forest subsidies as a possible political incentive instrument to promote the conversion to climate-stable forests. However, in his opinion, this would require a fundamental revision of the funding criteria: "At present, funding is provided in such a way that those who build a fence practically clear it and plant trees there receive funding, and those who do a much better job ecologically, produce a great result, receive nothing. We should promote according to the result, and with that, we could set a completely different course through policy" (IP 14, Pos. 134).

The debates about the forest of the future were characterized by climate change on the one hand and growing demands on multifunctional forests on the other. This also raised questions about the property rights of forest owners and the possibilities of monetizing ecosystem services. The surveyed stakeholders agreed that it was necessary and justified to relieve the burden on forest owners (IP 1, IP 3, IP 4, IP 10, IP 18, IP 23, IP 26). The managing director of a large association of forest owners formulated the desire for a political and social rethinking in such a way that "a price is paid to the forest industry for the positive external effects and public goods" (IP 23, Pos. 32). Forest owners had an economic interest in this. They saw it as a source of income that can at least partially compensate for the losses caused by drought, beetle infestation, etc. [IP 23]. A representative of nature conservation urged to act with a sense of proportion in such control instruments and to keep climate and nature conservation in mind together: "The fight against climate change has become more important [ ... ] but I think the biodiversity crisis is the second big crisis. [ ... ] I think it is a pity that the authorities are not aware of this" (IP 13, Pos. 39-43).

Table 3 picks up the derived associations from Table 2 and links them to the proposed measures put forward by the interview partners. These result in demands that can be summarized in two main complexes. Firstly, those that relate to the forest as a place of primary production and demand silvicultural adjustments. The second complex refers rather to the handling of the raw material wood, which must be accompanied by a high measure of planning security. As with the associations (see Table 2), no regional disparities could be identified.

From all sides, political actors were thus assumed a certain inertia. Despite their different professions, all interviewees agreed that the government had a duty to provide a consistent framework for forest management and wood processing. More action and less reaction were required. They should "say that this is the direction we should take and that is what we imagine for Germany [ ... ] or for this region" (IP 26, Pos. 118). 
Table 3. Demands on politics by the interview partners.

\begin{tabular}{|c|c|c|}
\hline Association Topic & Measures & Demands \\
\hline \multirow{7}{*}{ Sustainability/raw material availability } & Additional areas for forestry & \multirow{7}{*}{$\begin{array}{l}\text { Forest-related demands for } \\
\text { adaption of forest management }\end{array}$} \\
\hline & Mobilize unused potentials & \\
\hline & Silvicultural adjustment, resilient forests & \\
\hline & Forest subsidies by pricing in external effects & \\
\hline & Ecologically oriented funding & \\
\hline & $\begin{array}{l}\text { Consistent framework for forest management } \\
\text { and wood processing }\end{array}$ & \\
\hline & Relieving forest owners & \\
\hline \multirow{7}{*}{ Business-related/innovation/substitution } & Reduction of value added taxes & \multirow{7}{*}{$\begin{array}{l}\text { Wood-related demands for } \\
\text { planning reliability }\end{array}$} \\
\hline & Financial compensation & \\
\hline & Adjust building regulations & \\
\hline & Include environmental costs & \\
\hline & $\mathrm{CO}_{2}$-tax & \\
\hline & Public sector $=$ trend setter & \\
\hline & Overcome inhibitory regulations & \\
\hline
\end{tabular}

\section{Discussing Necessary Change and Forms of Critique}

The perceptions of bioeconomies also included forms of criticism that should be taken into account when striving for broad social acceptance. The critical voices emphasizing the limits of growth pointed out that approaches such as sufficiency or post-growth were not sufficiently taken into account in bioeconomies. For a comprehensive change, it would not be sufficient to replace all non-bio-based raw materials. A recent monitoring of German bioeconomy also points out that additional efforts are needed [37]. In addition, Hausknost et al. have presented other visions of bioeconomies beyond the emphasis on biotechnology and growth [9]. The substitution of fossil raw materials also challenged the understanding of sustainability if it encompassed more than the reference to Carlowitz. Nicolas Georgescu-Roegens, who coined the term bioeconomy, thus described a growth-critical and ecological economic science [38,39].

Talking about (wood-based) bioeconomies, the question arose of whether forestry and wood industry were not already engaged in bioeconomies. After all, they already sustainably managed a renewable raw material. Or was it rather biotechnological innovation that would transform forestry in the future? These two competing interpretations (biological raw material vs. biotechnological production) also reflected the state of research in the forestry sector [6,9]. Two interviewees saw the forestry and wood sector as the most important field of action for bioeconomies. The fact that this was a 'key sector' of bioeconomies has already been highlighted in a study on the positions of stakeholders in the forestry and wood sector [26]. In the present study, it is noticeable that those who were active in political work hold this position. They, therefore, fitted the criteria of interview partners who have already publicly expressed their views on the topic and were politically active.

The results in Tables 2 and 3 call for measures to promote the processing of raw materials (wood-related measures). This promotion could be achieved by stimulating wood utilization (reduction of value-added tax, public sector as trendsetter, etc.) or restricting competing raw materials or processes $\left(\mathrm{CO}_{2}\right.$-tax, building regulations, etc.) This adds to and specifies the suggestions made by Pannicke et al. for political actions [4]. More than half of the required forest-related measures are not linked to the raw material, but to the production base. This means that an increased use of wood risks to jeopardize the arguments (Table 2) of the raw material ("wood = organic = sustainable", regional cycles, etc.) which are perceived as positive. The distinction between forest-related and wood-related demands also reflects the dichotomy of the interpretations of bioeconomies described above. The question of more state regulation or liberalization has traditionally had a high potential 
for conflict in forest policy. While representatives of the economy, such as (private) forest owners, usually opposed state influence [40], the German Advisory Council on the Environment, a scientific advisory board of the German government, tends to demand more [41]. Additionally, the question arose in what form the state exerts or should exert influence. For the future of wood-based bioeconomies, however, all interviewees demanded more state intervention, as described above. Despite individual differences in detail, representatives from business and industry agreed with those from environmental protection and nature conservation, other associations or forest managers that there was a lack of a consistent strategy on the part of political decision-makers. What was the cause for this? Were the actors simply overwhelmed by the complexity of the issue? On the other hand, the vast majority of interviewees could present decisive ideas on how politics should intervene. The necessity of binding $\mathrm{CO}_{2}$ in the long term was repeatedly referred to. However, if wood were to replace other fossil raw materials, lock-in effects would first have to be overcome. Hagemann et al. conclude that a decided bioeconomy policy is lacking and therefore bioeconomy was always a "by-product of other policies" [5] (p. 17). With a different methodological approach, Purkus et al. also came to this conclusion. They demanded a clear political framework. On the one hand, this should eliminate competitive factors that inhibit bioeconomic processes (enabling function). On the other hand, non-sustainable use paths should be consistently restricted and successively sorted out (restriction function). They justified the necessity of a regulatory framework with various examples of mutually influencing market failures that made it impossible for the markets alone to fulfill these functions, or to overcome the lock-in in the fossil-based economy [42]. Pannicke et al. also concluded that politics should make a clear and long-term commitment to the biobased transformation process. In their view, the success of a sustainable change towards biobased management depended strongly on the innovation performance of the stakeholders. They, therefore, suggested that the political framework should focus on sustainable production and recycling management [4].

\section{Conclusions}

Relevant actors in wood-based bioeconomies hardly dealt with the goals and contents of political bioeconomy strategies in their everyday lives. Only a few were familiar with the term and even among these, there were different associations. Bioeconomies was not recognized as the holistic concept it is meant to be since everyone only saw a part of the picture. The problems and obstacles they faced in their day-to-day business become eo ipso problems and obstacles of the wood-based bioeconomies. The assumption that the different conditions prevailing in the chosen regions lead to different perceptions of bioeconomies could not be confirmed in the interviews. Although the problems and conflicts facing the actors in their respective regions were different, this does not affect the perception of bioeconomies and the resulting political demands.

To initiate necessary changes, the actors first expected politicians to provide reliable framework conditions for the promotion of bioeconomic solutions. As other studies have shown, it is up to political actors to contribute to the definition of concepts by sending clear political signals and thus influence the behavior of actors and potential opinion leaders. This means that some future areas of conflict in bioeconomies will also emanate from the term itself. Some of the actors' associations were again very close to Nicolas Georgescu-Roegens' originally proposed meaning as a growth-critical and ecological economic science. There is a danger that bioeconomies will be perceived as a 'business-as-usual' strategy in which only the raw material base is substituted by another. However, bioeconomies are not simply the connection of biology and economy, society, etc., but the relations between these many different areas. Birch states: "conceptually linking 'biology' with economies, knowledges and societies by affixing 'bio-' to the front of one word or another ignores the more difficult work of understanding the complex, evolving relations between these (very different) things" [43] (p. 916).

The question of whether (wood-based) bioeconomies are rather technological or biomass-orientated was not relevant to the actors in this study. On the other hand, the view that bioeconomies cannot function without wood as a raw material was, as expected, widespread in this sample from the 
forestry and wood sector. Irrespective of how the question "Where does the raw material come from?" is answered, however, reflexive answers from the interviewees are a clear indication that the question is relevant for many actors and thus probably also for many other people. A future communication strategy for bioeconomies must prepare itself for pressing questions about primary production.

The actors interviewed for this paper are convinced that wood is the key raw material for bioeconomies. This means that the raw material aspects must be given greater weight in further discussions. The advantages and disadvantages of forest-based production thus become important problems for the bioeconomy and need to be addressed in further policies. This is accompanied by a need for a change in language: While the term "wood-based" mentally excludes primary production, the term "forest-based" includes the entire production chain from the very beginning. Given that, one should consider changing the title of this article.

For forest-based bioeconomies, several conflicts will take place close to primary production. This involves very fundamental questions such as: Where can humans intervene in the forest? How can they do so? What should the forest look like and for whom and what is it there for? Should trees be felled at all? The demands made on the forest are manifold and the question of how to handle wood is always connected to this. These questions are closely linked to the concept of multifunctional forestry and, for example, the question of biodiversity. It is to be expected that these discussions will intensify as concepts of bioeconomies become more widespread.

Author Contributions: Conceptualization, data curation, investigation, methodology, validation, visualization, writing—original draft preparation: M.H., J.S., L.F.; funding acquisition: A.P., J.S., L.F., R.J.; project administration: J.S., L.F.; supervision: A.P., R.J.; writing-review \& editing: M.H., J.S., L.F., A.P., R.J. All authors have read and agreed to the published version of the manuscript.

Funding: This work was funded by the Federal Ministry of Food and Agriculture based on a resolution of the German Bundestag within the framework of the Renewable Resources Funding Programme (FKZ: 22015516).

Acknowledgments: The authors thank C. Eicher, R. Gabele, D. Masarovic, S. Messmer, S. Mutschler and A. Schmidt for their support in transcribing and fieldwork. We further acknowledge support by Open Access Publishing Fund of University of Tübingen.

Conflicts of Interest: The authors declare no conflict of interest. The funders had no role in the design of the study; in the collection, analyses, or interpretation of data; in the writing of the manuscript, or in the decision to publish the results.

\section{References}

1. BMBF; BMEL. Nationale Bioökonomiestrategie. 2020. Available online: https://www.bmbf.de/upload_ filestore/pub/BMBF_Nationale_Biooekonomiestrategie_Langfassung_deutsch.pdf (accessed on 21 July 2020).

2. Meyer, R. Bioeconomy Strategies: Contexts, Visions, Guiding Implementation Principles and Resulting Debates. Sustainability 2017, 9, 1031. [CrossRef]

3. Georgescu-Roegen, N. The Entropy Law and the Economic Process; Harvard University Press: Cambridge, UK, 1971; ISBN 9780674281653.

4. Pannicke, N.; Gawel, E.; Hagemann, N.; Purkus, A.; Strunz, S. The political economy of fostering a wood-based bioeconomy in Germany. Ger. J. Agric. Econ. GJAE 2015, 64, 224-243.

5. Hagemann, N.; Gawel, E.; Purkus, A.; Pannicke, N.; Hauck, J. Possible Futures towards a Wood-Based Bioeconomy: A Scenario Analysis for Germany. Sustainability 2016, 8, 98. [CrossRef]

6. Backhouse, M.; Lorenzen, K.; Lühmann, M.; Puder, J.; Rodríguez, F.; Tittor, A. Bioökonomie-Strategien im Vergleich: Gemeinsamkeiten, Widersprüche und Leerstellen; Bioeconomy \& Inequalities Working Paper No. 1; Friedrich Schiller University Jena: Jena, Germany, 2017; Available online: https://www.bioinequalities.unijena.de/sozbemedia/neu/2017-09-28+workingpaper+1.pdf (accessed on 21 July 2020).

7. Levidow, L.; Birch, K.; Papaioannou, T. EU agri-innovation policy: Two contending visions of the bio-economy. Crit. Policy Stud. 2012, 6, 40-65. [CrossRef]

8. Staffas, L.; Gustavsson, M.; McCormick, K. Strategies and Policies for the Bioeconomy and Bio-Based Economy: An Analysis of Official National Approaches. Sustainability 2013, 5, 2751-2769. [CrossRef] 
9. Hausknost, D.; Schriefl, E.; Lauk, C.; Kalt, G. A Transition to Which Bioeconomy? An Exploration of Diverging Techno-Political Choices. Sustainability 2017, 9, 669. [CrossRef]

10. McCormick, K.; Kautto, N. The Bioeconomy in Europe: An Overview. Sustainability 2013, 5, $2589-2608$. [CrossRef]

11. Kleinschmit, D.; Lindstad, B.H.; Thorsen, B.J.; Toppinen, A.; Roos, A.; Baardsen, S. Shades of green: A social scientific view on bioeconomy in the forest sector. Scand. J. For. Res. 2014, 29, 402-410. [CrossRef]

12. Hedeler, B.; Lettner, M.; Stern, T.; Schwarzbauer, P.; Hesser, F. Strategic decisions on knowledge development and diffusion at pilot and demonstration projects: An empirical mapping of actors, projects and strategies in the case of circular forest bioeconomy. For. Policy Econ. 2020, 110, 102027. [CrossRef]

13. Grundel, I.; Dahlström, M. A Quadruple and Quintuple Helix Approach to Regional Innovation Systems in the Transformation to a Forestry-Based Bioeconomy. J. Knowl. Econ. 2016, 7, 963-983. [CrossRef]

14. Iversen, E.; Capasso, M.; Rørstad, K. Actors and innovators in the circular bioeconomy. In From Waste to Value; Klitkou, A., Fevolden, A.M., Capasso, M., Eds.; Routledge: Abingdon, UK; New York, NY, USA, 2019; pp. 211-230. ISBN 9780429460289.

15. Leipold, S.; Petit-Boix, A. The circular economy and the bio-based sector-Perspectives of European and German stakeholders. J. Clean. Prod. 2018, 201, 1125-1137. [CrossRef]

16. Falcone, P.M.; González García, S.; Imbert, E.; Lijó, L.; Moreira, M.T.; Tani, A.; Tartiu, V.E.; Morone, P. Transitioning towards the bio-economy: Assessing the social dimension through a stakeholder lens. Corp. Soc. Responsib. Environ. Manag. 2019, 26, 1135-1153. [CrossRef]

17. López Hernández, V.; Schanz, H. Agency in actor networks: Who is governing transitions towards a bioeconomy? The case of Colombia. J. Clean. Prod. 2019, 225, 728-742. [CrossRef]

18. Zeug, W.; Bezama, A.; Moesenfechtel, U.; Jähkel, A.; Thrän, D. Stakeholders' Interests and Perceptions of Bioeconomy Monitoring Using a Sustainable Development Goal Framework. Sustainability 2019, 11, 1511. [CrossRef]

19. Johansson, J. Collaborative governance for sustainable forestry in the emerging bio-based economy in Europe. Curr. Opin. Environ. Sustain. 2018, 32, 9-16. [CrossRef]

20. Vainio, A.; Ovaska, U.; Varho, V. Not so sustainable? Images of bioeconomy by future environmental professionals and citizens. J. Clean. Prod. 2019, 210, 1396-1405. [CrossRef]

21. Gobo, G. Doing Ethnography; Reprint; SAGE: London, UK, 2010; ISBN 9781412919203.

22. Ehn, B.; Löfgren, O.; Wilk, R.R. Exploring Everyday Life: Strategies for Ethnography and Cultural Analysis; Rowman \& Littlefield: Lanham, MD, USA, 2016; ISBN 9780759124066.

23. Harrison, A.K. Ethnography: Unterstanding Qualitative Research; Oxford University Press: New York, NY, USA, 2018; ISBN 9780199371785.

24. Avelino, F.; Wittmayer, J.M. Shifting Power Relations in Sustainability Transitions: A Multi-actor Perspective. J. Environ. Policy Plan. 2016, 18, 628-649. [CrossRef]

25. Stebbins, R.A. Exploratory Research in the Social Sciences; SAGE Publications: Thousand Oaks, CA, USA, 2001; ISBN 0761923985.

26. Stein, M.; Giurca, A.; Kleinschmidt, D. “Wir sind die Bioökonomie"-Perspektiven von Akteuren aus dem deutschen Forst- und Holzsektor. Allg. Forst Jagdztg. (AFJZ) 2018, 189, 30-40. [CrossRef]

27. Kelle, U. The Development of Categories: Different Approaches in Grounded Theory. In The SAGE Handbook of Grounded Theory; Bryant, A., Charmaz, K., Eds.; SAGE Publications: London, UK, 2011; pp. 191-213. ISBN 9781412923460.

28. Hammersley, M.; Atkinson, P. Ethnography: Principles in Practice; Reprint; Routledge: London, UK, 2009; ISBN 9780415396042.

29. Mason, M. Sample Size and Saturation in PhD Studies Using Qualitative Interviews. Forum Qual. Soc. Res. 2010, 11, 8. [CrossRef]

30. Bourdieu, P. The Field of Cultural Production: Essays on Art and Literature; Columbia University Press: New York, NY, USA, 1993; ISBN 0231082878.

31. Haraway, D. Situated Knowledges: The Science Question in Feminism and the Privilege of Partial Perspective. Fem. Stud. 1988, 14, 575-599. [CrossRef]

32. Lühmann, M. Wessen Bioökonomie für Europa? Die Ausrichtung der EU-Bioökonomiepolitik nach ihrer Aktualisierung; Bioeconomy \& Inequalities Working Paper No. 4; Friedrich Schiller University Jena: 
Jena, Germany, 2019; Available online: https://www.bioinequalities.uni-jena.de/sozbemedia/neu/neu/2019_ 01_12+working+paper+4.pdf (accessed on 21 July 2020).

33. Rosenthal, G. Interpretive Social Research: An Introduction; Göttingen University Press: Göttingen, Germany, 2018; ISBN 9783863953744.

34. BMBF. Nationale Forschungsstrategie BioÖkonomie 2030: Unser Weg zu Einer Bio-Basierten Wirtschaft. 2010. Available online: https://www.bmbf.de/pub/Nationale_Forschungsstrategie_Biooekonomie_2030.pdf (accessed on 21 July 2020).

35. BMEL. Nationale Politikstrategie Bioökonomie: Nachwachsende Ressourcen und Biotechnologische Verfahren als Basis für Ernährung, Industrie und Energie. 2014. Available online: https://www.bmel.de/SharedDocs/ Downloads/DE/Broschueren/Biooekonomiestrategie.pdf;jsessionid=5FC7534E0CDA6F927E377AFCFB0997A5. internet2852?_blob=publicationFile\&v=3 (accessed on 21 July 2020).

36. Von Carlowitz, H.C. Syvicultura Oeconomica: Oder Haußwirthliche Nachricht und Naturmäßige Anweisung Zur Wilden Baum-Zucht; Johann Friedrich Braun: Leipzig, Germany, 1713.

37. Bringezu, S.; Banse, M.; Ahmann, L.; Bezama, A.; Billig, E.; Bischof, R.; Blanke, C.; Brosowski, A.; Brüning, S.; Borchers, M.; et al. Pilotbericht zum Monitoring der Deutschen Bioökonomie. 2020. Available online: https://kobra.uni-kassel.de/bitstream/handle/123456789/11591/ PilotberichtMonitoringBiooekonomie2020.pdf?sequence=6\&isAllowed=y (accessed on 9 October 2020).

38. Georgescu-Roegen, N. Inequality, Limits and Growth from a Bioeconomic Viewpoint. Rev. Soc. Econ. 1977, 35, 361-375. [CrossRef]

39. Georgescu-Roegen, N. Bioeconomics and ethics. In From Bioeconomics to Degrowth: Georgescu-Roegen's "New Economics" in Eight Essays; Bonaiuti, M., Ed.; Routledge: London, UK, 2011; pp. 142-145. ISBN 9780415587006.

40. Borchers, J. Segregation versus Multifunktionalität in der Forstwirtschaft. Forst Holz 2010, 65, 44-49.

41. Sachverständigenrat für Umweltfragen. Umweltgutachten 2012: Verantwortung in Einer Begrenzten Welt; Erich Schmidt Verlag: Berlin, Germany, 2012; ISBN 9783503138982.

42. Purkus, A.; Hagemann, N.; Bedtke, N.; Gawel, E. Towards a sustainable innovation system for the German wood-based bioeconomy: Implications for policy design. J. Clean. Prod. 2018, 172, 3955-3968. [CrossRef]

43. Birch, K. The problem of bio-concepts: Biopolitics, bio-economy and the political economy of nothing. Cult. Stud. Sci. Educ. 2017, 12, 915-927. [CrossRef]

Publisher's Note: MDPI stays neutral with regard to jurisdictional claims in published maps and institutional affiliations.

(C) 2020 by the authors. Licensee MDPI, Basel, Switzerland. This article is an open access article distributed under the terms and conditions of the Creative Commons Attribution (CC BY) license (http://creativecommons.org/licenses/by/4.0/). 